\title{
RESÚMENES/ABSTRACTS
}

Salvar la ciencia

Daniel Sarewitz

[Palabras clave: transcientífico, ciencia, innovación, valor público, responsabilidad social; JEL: A11, A13]

La ciencia enfrenta una crisis multifacética -de calidad, valor público y legitimidad política- cuyo origen es, en gran medida, la creencia de que la simple curiosidad científica ayuda a resolver problemas científicos y sociales. Este artículo muestra que esa creencia afecta cada vez más la capacidad de la empresa científica para satisfacer los estándares de alta calidad y las necesidades de la sociedad, a pesar de su creciente productividad. Contrasta el ideal de la libre investigación con episodios reales de interrelación entre ciencia, innovación y solución de problemas después de la Segunda Guerra Mundial. Y, con ejemplos actuales e históricos, muestra que es necesario vincular más estrechamente la creación de conocimiento a la solución de problemas para que la ciencia recupere su integridad y cumpla sus promesas y su responsabilidad con la sociedad.

\section{Saving science}

Daniel Sarewitz

[Keywords: transcient, science, innovation, public value, social responsibility; JEL: A11, A13]

Science is facing a multi-faceted crisis: in terms of quality, of public value, of political legitimacy. To a significant degree, these problems find their origin in the widely held belief that unfettered scientific curiosity provides the best starting point or departure for solving both scientific and social problems. In this article I show how this belief has contributed to a scientific enterprise whose exponentially growing productivity is increasingly decoupled from meeting the standards of high quality or the needs of society. I contrast the ideals of unfettered scientific inquiry with real stories of how science, innovation, and problem solving came together in the institutional arrangements of the "military-industrial complex" after World War II. Through an array of contemporary and historical examples stronger links, I show 
how stronger links between the context of knowledge creation, and the context of problem solving, provides the pathway along which science can recover both its integrity and its commitment to society.

\section{¿A dónde van las universidades? Perspectivas histórica y comparativa Stefan Collini}

[Palabras clave: intimidación incesante; políticas; instituciones; educación superior; JEL: I21, I23, I24]

Este artículo examina la tendencia de las universidades a adoptar criterios y pautas de evaluación propios de las empresas de negocios. Ante la masificación de la matrícula y los costos de funcionamiento, privilegian los aspectos administrativos sobre los académicos. Quizá no sea un signo de decadencia, pero su orientación ha cambiado radicalmente en comparación con la de hace tres o cuatro décadas. De continuar esta tendencia, la preocupación por el uso "racional" del personal y la planta física y el reclutamiento de profesores más dedicados a la contratación que a la docencia y a la investigación básica acentuarán la distancia entre universidades de élite y el resto de universidades, que al perder sus características peculiares solo capacitará personal para el mercado de trabajo.

What's Happening to Universities? Historical and Comparative Perspectives

Stefan Collini

[Keywords: incessant intimidation; policies; institutions; higher education JEL: I21, I23, I24]

This article examines the tendency of universities to adopt criteria and evaluation guidelines specific to business enterprises. Faced with the massification of enrollment and operating costs, they favor the administrative roles of academics tend to be more favored. While being a sign of academic decay, there has undoubtedly has been radical change during the last four decades ago. If this trend continues, concern about the "rational" use of staff and the physical plant and the hiring of professors more engaged in recruitment than teaching and basic research will accentuate the distance between elite universities and other universities, that and its distinct academic role will change as its focus will be training personnel for the labor market. 
Elección social, desigualdad y virtud civica

Mauricio Uribe López

[Palabras clave: elección social, pobreza, política social, preferencias reveladas, republicanismo, desigualdad; JEL: D63, D69, D71]

Este artículo muestra que Amartya Sen vincula la teoría de la elección social a la búsqueda razonada de la justicia, incorporando información moral distinta de las comparaciones interpersonales, la cual incluye la agencia como compromiso que remite a la noción de virtud cívica. Argumenta que la superación de la pobreza y la desigualdad extrema en América Latina, no es una simple cuestión de ingeniería social basada y que depende del aumento de la aversión a la desigualdad y de la acción política de los ciudadanos.

Social choice, inequality and civic virtue

Mauricio Uribe López

[Keywords: social choice, poverty, social policy, revealed preferences, republicanism, inequality; JEL: D63, D69, D71]

The article presents the way in which Sen attachs the social choice theory to the reasoned search for justice, taking into account interpersonal comparisons such as different kinds of moral information. These types of information is the concept of agency linked to the republican idea of civic virtue. The goal is to lay out the argument according to which overcoming poverty and extreme inequality in Latin America, cannot be achieved if taken only as a matter of social engineering. The viability of this objective depends not only on the increasing - its depends on citizens' disdain for inequality, but also to citizen's political action and its impact on public policy.

Inversión en intangibles y estrategia competitiva: una extensión del modelo de Cournot

Gloria Inés Sarmiento y Oscar Arturo Benavides

[Palabras clave: capital intangible, estrategia competitiva, poder de mercado; JEL: L11, L12, L21, O31]

En la creciente literatura sobre capital intangible hay un consenso relativo sobre su papel: las firmas dedican recursos a producirlo para 
obtener ventajas competitivas. Este artículo presenta un modelo en el que las firmas compiten à la Cournot, el cual explora los incentivos de las firmas para aumentar el nivel de capital intangible y muestra que si una firma es suficientemente productiva en la creación de capital intangible puede obtener mayores beneficios que sus competidores y poder de mercado aun en competencia perfecta.

Investment in intangibles and competitive strategy: an extension of the Cournot model

Gloria Inés Sarmiento y Oscar Arturo Benavides

[Keywords: intangible capital, competitive strategy, market power; JEL: L11, L12, L21, O31]

The growing literature on intangible capital shows a relative consensus on the role of firms in terms of investing resources to acquire (purchase or produce) this type of capital because it allows them to obtain a competitive advantage. This paper explores the incentives of In increasing their level of intangible capital using a simple model in which the firms compete a la Cournot. The model shows that the firm can get higher price-cost margins and market share than its rivals even in perfect competition given that the firm is productive enough in the production of intangible capital.

\section{La naturaleza de las instituciones. El debate actual \\ Gabriel Guzmán y Cristian Frasser}

[Palabras clave: ontología de la sociedad, ontología de las instituciones, John Searle, reglas, acción por incentivos; JEL: B41, B52, Y8]

En este artículo se discute la ontología de las instituciones y se critica la idea de que las instituciones están hechas únicamente de incentivos y acciones individuales. Se sostiene, además, que las instituciones no están constituidas únicamente por acciones de individuos, y que poseen una ontología propia, reglada y lingüística. Se comparan diversos enfoques sobre el tema y se presentan dos líneas de investigación sobresalientes en la literatura: el intento de construir una teoría unificada de las instituciones y una propuesta para incluir las reglas constitutivas en la teoría de juegos. 
The nature of institutions. The current debate

Gabriel Guzman y Cristian Frasser

[Keywords: ontology of society, ontology of institutions, John Searle, rules, incentive action; JEL: B41, B52, Y8]

This article discusses the ontology of institutions and criticizes the notion that institutions are made only of incentives and individual actions. It is further argued that institutions are not constituted solely on the actions of individuals, and that they have a proper, regulated and linguistic ontology. Several approaches are compared on the subject and two main lines of research are identified in the literature: the attempt to construct a unified theory of institutions and a proposal to include constitutive rules in game theory.

Auge minero y desindustrialización en América latina

Edwin Torres Gómez y Mauricio López González

[Palabras clave: ciclo económico, enfermedad holandesa, industria, minería, exportaciones; JEL: E32, F14, F41, L71]

La producción minera creció notablemente en América Latina en las dos últimas décadas y el auge de sus exportaciones redujo la producción y la exportación de bienes industriales, provocando la enfermedad holandesa. Este estudio explora sus efectos empleando un modelo de regresión con datos de panel y un análisis gráfico de regresiones locales polinómicas. Los resultados indican que la minería desplaza a la industria en aquellos países donde las exportaciones mineras superan cierto umbral, el cual debe servir de alarma para que las autoridades económicas intervengan en forma activa.

\section{Mining boom and deindustrialization in Latin America Edwin Torres Gómez y Mauricio López González}

[Keywords: economic cycle, dutch disease, industry, mining, exports; JEL: E32, F14, F41, L71]

Mining production has grown substantially in Latin America in the last decades. This boom has adversely affected the negatively the production and exports of manufacturing goods, suggesting the basis for the phenomena of the "Dutch Disease". This study allows 
ratifying that incidence through a regression model with panel data and a graphical analysis using local polynomial regressions. Results show a trade off in production and exports between two important sectors, industry and mining. The negative relationship operates in countries where exports of mining goods exceed a certain threshold, wich is the moment at which economic institutions should set off the alarms and intervene on a more active way. This research has named "Intersectoral Substitution Curve" Isc to this phenomenon.

Aversión al riesgo, preferencia temporal y variables socioeconómicas: evidencia de un pueblo de Colombia

David Ortiz Escobar

[Palabras clave: experimentos de campo, preferencia temporal, aversión al riesgo, desplazamiento; JEL: C93, D91, O54]

En este artículo presento evidencia exploratoria para el caso de Colombia sobre la relación entre ciertas variables socioeconómicas e indicadores de preferencias individuales. Aplicamos una encuesta de hogares y tomamos medidas de preferencia temporal y aversión al riesgo a una muestra de habitantes de Barranca de Upía (Meta). Encuentro que i. La edad está asociada con la preferencia temporal revelada, pero no a la aversión al riesgo revelada; ii. Las mujeres son más aversas al riesgo, y iii. El hecho de haber llegado al pueblo en los últimos cinco años, bien sea buscando oportunidades económicas o huyendo del conflicto armado, está asociado a una alta preferencia temporal revelada y una baja aversión al riesgo revelada.

Risk aversion, temporal preference, and socioeconomic variables: evidence from a Colombian people

David Ortiz Escobar

[Palabras clave: field experiments, temporary preference, risk aversion, displacement; JEL: C93, D91, O54]

This is a Colombian case study which demonstrates the relationship. We applied a household survey and took measures of temporary preference and risk aversion to a sample of inhabitants of Barranca de Upía (Meta). I find that i. Age is associated with the time preference revealed, but not risk aversion is revealed; ii. Women are more risk averse, and iii. The fact that they have come to the village in the last 
five years, whether looking for economic opportunities or fleeing armed conflict, the revealing of a high temporal preference and a low risk aversion.

La duración del desempleo de los jóvenes y los "ninis" en Cali

Jhon James Mora, Carolina Caicedo Marulanda y Carlos G. González

[Palabras clave: jóvenes, duración del desempleo, "ninis”, endogeneidad del desempleo; JEL: J16, J64, C26, C41]

Este artículo discute las características de la duración del desempleo de los jóvenes caleños entre 2012 y 2013. Los resultados muestran que los jóvenes afrodescendientes, las mujeres y vivir en ciertas comunas aumentan la probabilidad de durar más tiempo desempleado. Además, analiza si la etnia, la educación, la ubicación en ciertas comunas, ser mujer, ser migrante aumenta o reduce la probabilidad de que un joven sea "nini" (ni trabaja ni estudia).

The duration of youth unemployment and the "ninis" in Cali Jhon James Mora, Carolina Caicedo Marulanda y Carlos G. González

[Keywords: young boys, duration of unemployment, "ninis", endogeneity of unemployment; JEL: J16, J64, C26, C41]

In this article, we discuss the characteristics of the employment duration for young people in Cali 2012-2013. Our results show that the Afro-descendent female youth and those residing in communas or slums have a higher probability of unemployment duration. On the other hand we analyze how ethnicity, women, location in a specific "Comuna", Migrant status impacts the probability of NEET conditions (Not in Employment, Education or Training).

Comercio mundial de bienes y servicios ambientales

Desempeño y retos de la industria mexicana

René Lara, Petr Sauer y Ludmila Sterbová

[Palabras clave: Política ambiental, desarrollo sustentable, comercio internacional, liberalización del intercambio; JEL: F13, F18 Q56, Q55, F53] 
Este artículo estudia las industrias ambientales de México y Estados Unidos en el marco del Tratado de Libre Comercio de América del Norte, donde la industria mexicana está rezagada por falta de fondos debido a las crisis económicas recurrentes. Si no se supera esa situación, los beneficios del comercio exterior para la industria ambiental mexicana seguirán siendo reducidos.

Global trade in environmental goods and services Performance and Challenges of Mexican Industry René Lara, Petr Sauer y Ludmila Sterbová

[Keywords: Environmental policy, sustainable development, international trade, liberalization of trade; JEL: F13, F18 Q56, Q55, F53] This article studies the environmental industries of Mexico and the United States Within the framework of the North American Free Trade NAFTA, where Mexican industry lags behind lack of funds due to recurring economic crises. Should this situation not be overcome, the benefits of foreign trade for the Mexican environmental industry will remain low.

Explotación de recursos naturales y conflicto en Colombia

Luis Eduardo Sandoval, Margarita Marín y Ana María Almanza

[Palabras clave: Recursos naturales, minería, conflicto, indicador; JEL: Q26, L71, Q34, C43]

Colombia se ha especializado en la extracción de recursos mineroenergeticos como oro, carbón, petróleo y ferroníquel. Estas actividades, en un contexto de debilidad estatal, han generado conflictos de diferentes dimensiones. E1 presente trabajo propone un indicador de conflicto relacionado con la explotación mineral, que permite clasificar cinco dimensiones de conflictividad: social, económica, cultural, política $\mathrm{y}$ ambiental. El indicador agregado muestra que los homicidios, la presencia de población afrodescendiente, las inundaciones, la contaminación, los incendios, la mortalidad infantil, los cultivos de coca y los delitos sexuales están altamente correlacionados con un mayor número de conflictos. 


\section{Exploitation of natural resources and conflict in Colombia}

Luis Eduardo Sandoval, Margarita Marín y Ana María Almanza

[Keywords: natural resources, mining, conflict, index; JEL: Q26, L71, Q34, C43]

Colombia has increasingly been specializing in the extraction of mineral and energy resources such as gold, coal, oil and ferronickel. These activities, in the context of state weakness, have engendered conflicts of different dimensions. This paper proposes an indicator of conflict related to mineral exploitation that classifies five dimensions of conflict: social, economic, cultural, political and environmental. The aggregate indicator shows that murders, displacement of Afrodescendent populations, flooding, pollution, fires, infant mortality, coca crops and sexual offenses are highly and positively correlated with the number of conflicts.

Redes criminales y corrupción en la era del microtráfico y el narcomenudeo Leonardo Raffo López y Diego Gómez Calderón

[Palabras clave: microtráfico, narcomenudeo, contiendas, corrupción y redes sociales; JEL: K42, D43, L13, C72, D85, D73]

Este artículo identifica y analiza los agentes, relaciones y procesos que caracterizan el desenvolvimiento del microtráfico de drogas y el narcomenudeo como fase actual del narcotráfico en Colombia. Se construye un modelo analítico con una estructura de juegos secuenciales y redes sociales que incorpora las estrategias de corrupción de los traficantes. El principal resultado es que una mayor represión puede ser contraproducente debido a reacciones estratégicas de los agentes que los inducen a invertir más recursos en corrupción.

Criminal networks and corruption in the era of microtraffic and narcomenuedeo

Leonardo Raffo López y Diego Gómez Calderón

[Keywords: Micro-drug trafficking, drug dealing, contests, corruption and social networks; JEL: K42, D43, L13, C72, D85, D73]

This study has sought to identify and analyze the key agents, relationships and processes characterizing the evolving of micro-drug traffic- 
king and retail-drug dealing as the present phase of drug-trafficking in Colombia. We build an analytical model in a sequential network game-theoretic structure, which takes into account the trafficker's corruption strategies. The most important finding is that Higher levels of reprisal could can be counterproductive due to the strategic responses of traffickers leading them to invest more resources invest in corruption activities. 